\title{
O LEQUE DE COGNOSCIBILIDADE DO PODER JUDICIÁRIO SOBRE QUESTÕES DE CONCURSO PÚBLICO PARA PROVIMENTO DE CARGOS EFETIVOS
}

\author{
José Luiz de Moura Faleiros Júnior ${ }^{164}$ \\ Brenda Rezende Pereira Rodrigues ${ }^{165}$
}

Recebido em: 10/08/2018

Aprovado em: 20/09/2018

\begin{abstract}
RESUMO
O presente trabalho propõe-se a analisar a Interferência do Poder Judiciário na revisão de questões de concursos públicos, delimitando os argumentos comumente utilizados pelas partes para compreender os posicionamentos jurisprudenciais usualmente adotados pelos tribunais pátrios. Para tanto, a presente pesquisa abordará as principais características do regime jurídico administrativo brasileiro, explicitando as normas e princípios norteadores da Administração Pública. Após, buscar-se-á compreender a categorização adotada para os agentes públicos, delimitando o funcionamento do exercício de suas funções. Assim, pelo método indutivo, ao apresentar posicionamentos jurisprudenciais dentro da temática abordada, averiguar-se-á a hipótese de uma postura minimalista por Parte do Judiciário no tocante ao mérito de questões de concurso cognoscíveis quando submetidas a seu crivo.
\end{abstract}

Palavras-chave: Concursos públicos. Questões. Poder Judiciário.

\section{INTRODUÇÃO}

Vivencia-se um cenário de crise econômica, de concursos públicos com concorrências assustadoras, desemprego e problemas políticos, o que suscita maior interesse no acesso a cargos públicos efetivos, haja vista as inegáveis vantagens que o pertencimento aos quadros da Administração Pública propicia, desde o valor da remuneração até a estabilidade.

Nesse contexto, é recrudescente o número de demandas submetidas ao Judiciário para a busca pela resolução de problemas relacionados aos concursos públicos, que são processos

\footnotetext{
${ }^{164}$ Mestrando em Direito pela Universidade Federal de Uberlândia - UFU. Especialista em Direito Processual Civil, Direito Digital e Compliance pela Faculdade de Direito Prof ${ }^{\circ}$ Damásio de Jesus. Advogado.

${ }^{165}$ Graduada em Direito pela Universidade Federal de Uberlândia - UFU. Advogada.
} 
administrativos cuja finalidade é garantir o provimento efetivo de cargos do serviço público em todos os seus níveis.

Em se tratando de processos administrativos, os concuros públicos podem envolver diversas fases, ficando a cargo da Administração Pública - com a observância dos preceitos que regem sua atuação - a nomeação de membros componentes de bancas, a elaboração e positivação de editais e a aplicação de provas prático-profissionais.

A vinculação do administrador público às normas constitucionais que norteiam o regime jurídico administrativo, cujo fim último é a proteção do regime democrático, impõe atenção especial às questões legais que envolvem a carreira e que norteiam o próprio funcionamento da máquina administrativa.

O atuar vinculado, quando eivado de desvios em face das previsões da legislação de regência dos procederes do administrador público, torna-se ato ilegal, e, assim, suscita-se a possibilidade de intervenção do Poder Judiciário para dirimir eventual abuso que configure nulidade, em festejo ao direito fundamental de inafastabilidade do controle jurisdicional, insculpido no artigo 5, incisos XXXIV, “a”, e XXXV, da Constituição da República.

Dessa forma, ao se deparar com atos ilegais praticados no curso de processos administrativos de concursos públicos, caberá ao Judiciário enfrentar a questão que lhe for levada pelo interessado, garantindo-se o acesso à justiça.

Forte nessas premissas, o presente trabalho almeja enfrentar o problema atinente ao leque de matérias congnoscíveis pelo Poder Judiciário no tocante às questões de concursos públicos, assunto de delicado jaez, haja vista o imperativo da separação dos poderes, que impõe limites para a atuação dos magistrados em relação aos administradores e a seus atos e decisões.

A hipótese de pesquisa, que parte do método indutivo fulcrado na pesquisa bibliográfica e na revisão de arestos dos tribunais pátrios, investigará se o minimalismo é o caminho mais adequado para o efetivo controle do Poder Judiciário acerca dessa matéria. A justificativa para a pesquisa proposta se lastreia justamente na relevância social que o tema ostenta quanto à crescente procura pelas carreiras públicas, que só faz aumentar a responsabilidade dos gestores públicos pela higidez dos certames de que lançam mão para o preenchimento de seus quadros.

Far-se-á, no primeiro capítulo, a apresentação do regime jurídico administrativo, de suas questões mais relevantes e dos princípios e da legislação norteadores do atuar administrativo com o fito de averiguar se a utilização dessas normas e princípios, na 
transcendência do plano teórico ao prático, propicia meios de atuação judiciária não intervencionista, em respeito à separação de poderes.

A partir dessa compreensão, avançar-se-á ao estudo sobre quem são os agentes públicos e sobre como se dá sua atuação no âmbito da Administração Pública, compreendendo-se, com isso, as delimitações que são impostas por sua forma de agir e por suas finalidades institucionais, sempre alertando para a perspctiva diferida com que a doutrina traz os conceitos de agentes públicos, servidores públicos e agentes em colaboração.

Comentar-se-á acerca das características que usualmente compõem os editais de concursos públicos na atualidade, suas normas de regência, das provas até a posse do candidato, garantindo-se uma visualização global do iter percorrido até a efetiva entrada em exercício, e como se adquire estabilidade ou vitaliciamento.

Fixado este panorama legal, proceder-se-á à discussão acerca do que seria ilegal e daquilo que se pode pedir remédio ao provocar a atuação do Poder Judiciário, enfrentando temas relacionados aos limites da discricionariedade do administrador.

Enfim, tratar-se-á do panorama geral dessa atuação judiciária, com alguns apontamentos acerca de seus fundamentos e de sua evolução jurisprudencial e do cenário atual, com o estudo de precedentes jurisprudenciais.

Ao final, apresentar-se-á conclusão na qual se destacará os desdobramentos do problema enfrentado em face da hipótese delineada, a fim de se constatar qual é a postura mais adequada, da parde do Poder Judiciário, para que possa ser esclarecido o grau de atuação e interferência que deve ter em conteúdos de questões de concursos públicos lançados pela Administração Pública, aferindo-se, com isso, seu leque de cognoscibilidade.

\section{O REGIME JURÍDICO ADMINISTRATIVO}

Inicialmente, se faz necessária uma compreensão sobre o funcionamento da Administração Pública sob um panorama geral, que viabilizará a devida compreensão acerca da necessidade de discussão do tema apresentado, uma vez que os princípios que regem a Administração Pública são determinantes para a solução da problemáticae, e, sendo assim, devem ser devidamente apresentados.

Destaca-se, inicialmente, que a Administração Pública ou as suas relações externas se diferem das relações privadas principalmente pela liberdade de seus atos. Entenda-se: as relações oriundas de direito privado são havidas em acordo com a vontade das partes, dentro 
da limitação legal, em busca de seus objetivos pessoais; as relações e atos estabelecidos pela Administração Pública são necessariamente submetidos aos princípios expressos e implícitos estabelecidos pela Constituição da República.

Segundo Fabrício Motta (2005, p. 139-140), uma vez que, dentro de uma democracia na qual a própria história gramatical da palavra se traduz na noção de "poder do povo", os atos administrativos devem se ater não apenas aos interesses do administrador, ganha ênfase o atendimento à vontade do povo, sendo a Administração Pública mera gerenciadora dos interesses desse, que é o verdadeiro titular do poder.

O regime democrático é marcado pela titularidade do poder conferida aos cidadãos, e de tal assertiva decorre o direito de participar ativamente do exercício e do controle das funções estatais. Sendo assim, os atos da Administração Pública são estabelecidos não por vontade pessoal de seus agentes, mas pela representação da vontade do povo, e, conforme alerta Ruth Araújo Viana (2011, p. 119-148), não há espaço para juízos discricionários norteados pelas valorações político-administrativas, que permaneçam isentas de quaisquer controles substantivos.

Nesse sentido, importante destacar o conceito de ato administrativo segundo Hely Lopes Meirelles (2016, p. 173): “[a]to administrativo é toda manifestação unilateral de vontade da Administração Pública que, agindo nessa qualidade, tenha por fim imediato adquirir, resguardar, transferir, modificar, extinguir e declarar direitos ou impor obrigações".

E, corroborando este entendimento, Juarez Freitas (2004) aponta a relevância dos princípios fundamentais no controle de tais atos, pelo que é seguido por Marcelo Harger (1998, p. 11-36) e Gustavo Binenbojm (2003, p. 208-212), realçando o fato de que todo agir administrativo está intrinsecamente conectado aos preceitos constitucionais, de onde se extrai seu fundamento precípuo de validade normativa e de legitimidade política.

Dessa forma, infere-se que o regime jurídico administrativo seria o conjunto de regras que incidem sobre a Administração Pública e que envolvem prerrogativas e obrigações para a preservação dos interesses da coletividade, ou seja, o regime que irá conduzir as ações e as concessões dentro da Administração do poder, emanado do povo, a partir de atos que serão editados por meio desses atos administrativos sob uma perspectiva garantista alinhada com o pensamento de Ferrajoli (2006), em contraposição à ideia de deslegitimação democrática.

Essa defesa do interesse primário está estabelecida dentro de direitos e deveres expressos e implícitos na legislação vigente no país, especialmente na Constituição da República, e, com o cunho exemplificativo, ressalta-se que se insere dentro do rol de deveres da Administração Pública a própria realização de concursos públicos (artigo 37, inciso II, da 
Constituição da República) para a investidura em seus cargos, além da contratação de serviços por meio de licitações (artigo 37, inciso XXI, da CR), da motivação imprescindível para a edição de qualquer ato da Administração Pública, e do pagamento via precatório, previsto no artigo 100 da Carta Política.

Já na esfera das prerrogativas da Administração Pública, destaca-se, para fins do contexto aqui tratado, a autoexecutoriedade, que dá à Administração Pública a independência na execução de seus atos, de forma que esta não precise de qualquer autorização, seja do Judiciário ou da parte que é atingida. Infere-se, também, as prerrogativas contratuais, as quais diferem-se muito dos contratos privados, uma vez que a Administração Pública pode, unilateralmente, alterar as regras aprovadas, e rescindir unilateralmente o contrato, sempre primando pelo atendimento do interesse público.

Pois bem, em relação aos princípios norteadores da atividade administrativa, elencamse os explícitos e os implícitos, sendo os primeiros dispostos no artigo 37 da Constituição da República e que têm como destinatária a Administração Pública, de forma que, estando dentro dos limites de sua atuação, somente se pode primar pelo interesse público. São os seguintes princípios: legalidade, impessoalidade, moralidade, publicidade e eficiência.

Nesse cenário, avançando para a fixação de premissas essenciais à compreensão do tema que será apreciado adiante, mister elucidar o papel do regime jurídico administrativo em face da constitucionalização ${ }^{166}$ que o Direito Administrativo passou a vivenciar em tempos recentes, levando o tema ao campo do debate democrático e politicamente propositivo sob o ponto de vista inclusivo (e não excludente) e informativo (e não deformativo) do ponto de vista político-institucional (GUASTINI, 2003, p. 50-58).

É com essa premissa que, segundo Bruno Miragem (2013, p. 31), “o Direito Administrativo, neste particular, redesenha um conjunto de instrumentos de colaboração", sendo que, nesse conjunto, estão inseridos temas que compreendem uma completa reestruturação da disciplina do Direito Administrativo, pela via da defesa e promoção dos direitos fundamentais.

Jaime Rodríguez-Arana Muñoz (2011, p. 87-102) alerta para o surgimento de um renovado regime administrativo cuja estruturação não fica adstrita exclusivamente à centralidade da dignidade humana. Em verdade, conforme sinaliza Cristiana Corrêa Conde Faldini (2010, p. 261-277), suas bases devem também dialogar e construir um espaço

\footnotetext{
${ }^{166}$ Fala-se, hodiernamente, em uma autêntica "revolução copernicana provocada pelo neoconstitucionalismo", que desencadeou o surgimento de uma nova hermenêutica constitucional que rompeu paradigmas no campo do Direito Administrativo, superando o positivismo jurídico e dando novos contornos ao tema. (STRECK, 2005, p. 521-523)
} 
dialético de conjugação com as dimensões normativas decorrentes do Estado democrático de direito e do princípio republicano, que constituem os três marcos estruturantes elementares à construção da Administração Pública democrática, comum ao novo regime jurídico administrativo.

O estudo do Direito Administrativo no Estado constitucional, segundo Binenbojm (2003, p. 735-743) suplanta a estática e fechada vinculação à estrita legalidade administrativa, submetendo a Administração Pública à vinculação ao princípio aberto e dinâmico da juridicidade administrativa, no sentido de que a atividade administrativa somente pode ser reconhecida como válida, legítima e adequada se estiver alinhada ao sistema de regras e princípios previstos na Constituição da República.

\section{AGENTES PÚBLICOS}

Tendo em vista que as nuances do presente tema implicam na investidura de pessoas nos cargos que compõem os quadros da Administração Pública, importante salientar quem são os tais agentes e em quais esferas administrativas exercem suas funções.

Nesse sentido, necessária a observância de alguns conceitos gerais acerca do tema, importantes para compreensão da sua atuação na esfera administrativa. Inicialmente, conceitua-se os agentes públicos, que são aqueles que, de alguma forma, estão ligados ao Poder Público e exercem funções - mesmo que transitórias - para a sociedade, por meio da Administração direita e indireta.

Assim, como existem diversas formas de exercer função ligada ao Poder Público, surge a necessidade doutrinária de classificar esses agentes, delimitando e compreendendo melhor suas funções dentro do Estado.

Face a esse conceito, conclui-se que, ao estarem ligados à Administração Pública direta e indireta, os agentes públicos se submetem, também, ao regime jurídico administrativo, devendo, no exercício de suas atividades, realizar atos que sejam submetidos aos princípios expressos e implícitos que cercam o regime, conforme anteriormente apresentado.

Logo, o interesse público deverá ser a finalidade e a justificativa de suas ações, e qualquer ato praticado em desacordo com a legislação e com os princípios que cercam tal atuação será ilegal e deverá ter remédio administrativo-jurídico para garantir o funcionamento legal dos órgãos que integram a Administração. 
Quanto à legislação regulamentadora dos agentes ligados à Administração Pública, tem-se as quatro esferas de governo (federal, estadual, distrital e municipal) com competência para legislar sobre a matéria. Assim, existem diversas legislações no país que especificam questões de acordo com suas necessidades, sempre em consonância com a legislação federal.

Nesse cenário, destacam-se algumas classificações gerais: a compreensão de quem são os agentes políticos, os servidores públicos e os agentes em colaboração.

De início, necessária a compreensão de que a presente classificação trata do vínculo pessoal do agente com a Administração Pública. Dessa maneira, destaca-se que os agentes políticos são detentores do comando da Administração Pública e exercem atividade governamental. Dessa forma, ressalta-se que os agentes públicos são membros de "Poder" (seja ele Legislativo, Executivo ou Judiciário), tratanto-se sempre do comando e do exercício das diretrizes da Administração Pública como um todo.

Carvalho Filho (2016, p. 752) aduz que os agentes políticos são aqueles que têm a incumbência de executar e agir em conformidade com as diretrizes traçadas pelo Poder Público, desenhando os destinos fundamentais do Estado ao atuar em direcionamento atrelado às estratégias políticas por eles consideradas necessárias e convenientes para que o Estado atinja os seus fins máximos.

A partir da definição de Carvalho Filho, tem-se que a compreensão de quem são os referidos agentes se torna lógica, na medida em que os representantes do Poder (Prefeitos, Governadores, Ministros do Supremo Tribunal Federal etc.) são auxiliados pelos seus Ministros de Estado e demais Secretários nas tomadas de decisões, que serão as diretrizes da Administração Pública, além dos detentores de mandato eletivo, que estão em direção do Poder Público. Nessa seara, percebe-se que os agentes públicos são, de fato, aqueles que ditarão os caminhos a serem seguidos pela Administração Pública.

Logo, é possível inferir-se que são estes os classificados como agentes públicos - em síntese, membros de Poder, detentores de mandado eletivo, Ministros de Estado, Secretários estaduais e municipais. Em regra, sua investidura se dá por eleição ou por nomeação, e suas diretrizes são encontradas na Constituição da República, que rege também suas atividades, diferentemente dos demais agentes públicos.

Os agentes particulares em colaboração são aqueles que desempenham algum tipo de função para a Administração Pública, mesmo sendo particulares. Sujeitam-se a certos encargos, não percebendo remuneração na hipótese, e sua atividade em relação à Administração Pública é considerada transitória. Um clássico exemplo desses agentes são os jurados convocados para realização de júri. 
Já os servidores públicos são a grande massa de prestadores de serviço à Administração, e são a ela vinculados por relações profissionais, como forma de emprego e mediante recebimento de pecúnia.

O Regime Jurídico Único é o estabelecido pela entidade estatal, no âmbito de sua competência, para todos aqueles que trabalham, tanto na administração direta, quanto nas autarquias e fundações, excluindo-se as empresas públicas e sociedades de economia mista; possuem o concurso público como forma majoritária de ingresso, formas e limites remuneratórios próprios, deveres e direitos, planos de carreira entre outros.

Dentro disso, cumpre ressaltar que sua forma de ingresso no serviço público é dada pela Constituição da República em seu artigo 37, caput e incisos I e II, que determina a realização de provas de concurso público de acordo com a lei e os legitimados para o cargo. Em relação à sua legitimação, destaca-se o artigo $5^{\circ}$ da Lei $n^{\circ} 8.112 / 90$, que aponta os requisitos básicos para tanto.

Sobre o tema, Celso Spitzcovsky (2013, p. 456) pontua o seguinte:

Oportuno destacar, contudo, que o legislador ainda abriu a possibilidade para a realização de novas exigências, desde que relacionadas com as atribuições do cargo, a teor do disposto no $\S 1$. $^{\circ}$ do mesmo dispositivo, como se observa:

"Art. 5. ${ }^{\circ}[\ldots]$

$[\ldots]$

$\S 1^{\circ}$ As atribuições do cargo podem justificar a exigência de outros requisitos estabelecidos em lei”.

É claro que essas outras exigências só terão legitimidade se guardarem compatibilidade com a natureza e a complexidade dos cargos e empregos a serem preenchidos, não ficando ao livre critério do administrador estabelecê-las.

Nota-se que, além dos requisitos básicos, é dada a garantia ao administrador público de criar outras exigências compatíveis com a legislação, especialmente norteadas pelo princípio da razoabilidade, de forma coerente com as disposições legais e também em sintonia com a sociedade e seus valores representativos, sem segregações e preconceitos.

Dessa forma, em acordo com o princípio da motivação, a formulação de outros requisitos deve possuir suas devidas razões para o adequado controle do Judiciário e para a garantia dos direitos daqueles que se sentirem lesados por eles.

Com efeito:

É bem verdade que nessas situações o perfil a ser conferido para o concurso público será outro, visto que terá ele um caráter interno, vale dizer, somente para aqueles que integram a Administração Pública e satisfizerem as exigências do cargo ou do emprego a serem preenchidos.

A diretriz não é gratuita, ao revés, decorre do princípio da eficiência, relacionado no caput do art. 37, e deve prevalecer para evitar que o preenchimento de cargos ou empregos para aqueles que estão dentro da estrutura da Administração seja realizado 
de maneira aleatória, por meio de critérios subjetivos. (SPITZCOVSKI, 2013, p. 459)

Observa-se que a Administração deve buscar os melhores sujeitos para integrar seus cargos, e, para tanto, os requisitos devem ser objetivos e coerentes com à função a ser exercida, evitando-se qualquer forma de subjetivismo na contratação de seus agentes, uma vez que as concepções pessoais do administrador não devem interferir na garantia da eficiência do trabalho exercido pela Administração Pública.

O estudo aqui apresentado, trata das relações jurídico-administrativas existentes pela forma de ingresso determinada pelo artigo 37, inciso II, do texto constitucional, tendo em vista que, conforme a determinação legal, o provimento nos cargos públicos deverá ser feito a partir (também) de concursos públicos.

\subsection{Breve histórico sobre a investidura em cargos públicos}

Inicialmente, cumpre observar que a investidura em cargo público por meio de concurso e o estabelecimento de seus regimes não é matéria recente na legislação brasileira. Tais conceitos vêm se estabelecendo em sede constitucional desde 1934, quando o artigo 90, $\S 1^{\circ}$, da Constituição da República daquele ano estabelecera, de modo taxativo, que ninguém poderia exercer função pública sem demonstração prévia de capacidade intelectual, que seria aferida mediante a realização de concurso. Isso porque, desde o início do Século XX, o Brasil já aderia à realização de concursos para o preenchimento de cargos públicos, tendo em vista a importância da função e a necessidade de comprovação de aptidões para o exercício.

Já a Constituição de 1937 manteve o caminho traçado pela constituição anterior, em seu artigo 122, inciso III, exigindo-se concurso apenas para a primeira investidura, em sintonia com o artigo 155, alínea "a". A Constituição que se seguiu, em 1946, manteve praticamente os mesmos termos, ainda sem adotar a denominação "concurso público", que somente apareceu na Constituição de 1967, a partir da exegese de seu artigo 97, com a exigência de concurso público para a investidura em cargos públicos.

Contudo, em que pese o estabelecido no artigo acima citado, observa-se que o Brasil passava por período político instável, razão pela qual a ressalva contida no $\S 1^{\circ}$ do artigo 97 , que abria espaços para disposições legislativas que "dispensassem" o concurso público, fazia com que o disposto no artigo não fosse seguido de maneira relevante, tendo em vista as conturbações políticas presentes à época. 
No mesmo sentido, quando o cenário político do Brasil foi alterado, com a volta da democracia e com a promulgação da Constituição da República de 1988, observou-se a exigência expressa de concursos públicos para a investidura em cargos públicos, temática que será discorrida detalhadamente nos tópicos subsequentes.

\section{$3.2 \mathrm{O}$ acesso a cargos públicos e suas características}

Apresentado o desenvolvimento histórico da investidura em cargos da Administração Pública, importante salientar as nuances principais do atual cenário legislativo e jurisprudencial acerca dos agentes públicos.

Primeiramente, cumpre ressaltar que as quatro esferas de governo podem legislar sobre o tema, sendo assim, cada Estado e Município pode ter suas especificidades quanto à matéria, desde que em sintonia com a Constituição vigente e com a Lei $n^{\circ}$ 8.112, de 1990, que trata do regime jurídico dos servidores públicos civis da União.

Nesse seguimento, a Constituição da República, em seu artigo 37, inciso I, traz a legitimação geral para titularizar os cargos, funções e empregos públicos (que se diferem pelo regime ao qual estão submetidos), os quais devem preencher os requisitos da lei.

No mesmo artigo supracitado, em seu inciso II, tem-se as hipóteses de investidura nas esferas administrativas, que adotam a regra geral do concurso público em diferentes etapas: aprovação, nomeação, posse e exercício do cargo.

Porém, a Constituição também trata dos cargos em comissão, que são de livre nomeação (artigo 37, inciso V), mas vedam ao administrador público o nepotismo, por força da Súmula Vinculante 13, do Supremo Tribunal Federal.

A referida Súmula Vinculante tem como propósito evitar o favorecimento de pessoas por motivações pessoais em detrimento de competências, inclusive na hipótese de nepotismo cruzado, na qual ocorre troca de favores para "driblar" a proibição.

Voltando aos concursos, importante salientar a previsão constitucional que assegura vagas dentro da Administração Pública para aqueles que possuem necessidades especiais (artigo 37, inciso VIII, CR/88), que garante a reserva de vagas de no mínimo 5\% e no máximo $20 \%$, sendo que os candidatos devem realizar as mesmas avaliações e comprovar que a deficiência não irá atrapalhar as necessidades de exercício do cargo conforme os enunciados de Súmula nºs 377 e 552 do Superior Tribunal de Justiça. 
Além dos deficientes, após o julgamento da Ação Declaratória de Constitucionalidade 41, 20\% das vagas devem ser reservadas aos afrodescendentes, a fim de propiciar a almejada inclusão social.

Pois bem, após a devida realização das provas e etapas dos processos seletivos, a primeira etapa percebida para investidura no cargo é a aprovação. Após essa fase, tem-se a nomeação. Porém, surge o seguinte questionamento: todo candidato aprovado tem direito a ser nomeado?

O direito à nomeação está relacionado ao número de vagas previstas em edital, assim, caso o candidato seja aprovado dentro do número de vagas, terá direito à nomeação até o término do prazo de validade do concurso (que é de dois anos, sendo permitida a prorrogação por igual período). Nessa hipótese, respeitando os princípios constitucionais, destaca-se o enunciado de Súmula $n^{\circ} 15$ do Supremo Tribunal Federal, que trata do respeito à ordem de classificação.

Quando o candidato é aprovado além do número de vagas, a Administração Pública não é obrigada a nomeá-lo, como na hipótese anterior, pois o aprovado, nesse caso, possui apenas expectativa do direito, mas não o direito em si.

Não obstante, em que pese o direito do candidato aprovado dentro da quantidade de vagas previstas à nomeação, existe respaldo jurisprudencial para desobrigar a administração a proceder à nomeação, e, para tanto, dentro do prazo de validade do concurso, a Administração poderá escolher o momento no qual se realizará a nomeação. Contudo, não poderá dispor sobre a própria nomeação, a qual, de acordo com o edital, passará a constituir um direito do concursando aprovado e, dessa forma, um dever imposto ao Poder Público.

Assim, uma vez publicado o edital do concurso com número específico de vagas, o ato da Administração que declara os candidatos aprovados no certame cria um dever de nomeação para a própria Administração e, portanto, um direito à nomeação titularizado pelo candidato aprovado dentro desse número de vagas.

Noutro norte, quando se afirma que a Administração Pública tem a obrigação de nomear os aprovados dentro do número de vagas previsto no edital, deve-se levar em consideração a possibilidade de situações excepcionalíssimas que justifiquem soluções diferenciadas, devidamente motivadas de acordo com o interesse público. Não se pode ignorar que determinadas situações excepcionais podem exigir a recusa da Administração Pública de nomear novos servidores.

O tema de repercussão geral foi julgado no Supremo Tribunal Federal: 
[...] Para justificar o excepcionalíssimo não cumprimento do dever de nomeação por parte da Administração Pública, é necessário que a situação justificadora seja dotada das seguintes características: a) Superveniência: os eventuais fatos ensejadores de uma situação excepcional devem ser necessariamente posteriores à publicação do edital do certame público; b) Imprevisibilidade: a situação deve ser determinada por circunstâncias extraordinárias, imprevisíveis à época da publicação do edital; c) Gravidade: os acontecimentos extraordinários e imprevisíveis devem ser extremamente graves, implicando onerosidade excessiva, dificuldade ou mesmo impossibilidade de cumprimento efetivo das regras do edital; d) Necessidade: a solução drástica e excepcional de não cumprimento do dever de nomeação deve ser extremamente necessária, de forma que a Administração somente pode adotar tal medida quando absolutamente não existirem outros meios menos gravosos para lidar com a situação excepcional e imprevisível. De toda forma, a recusa de nomear candidato aprovado dentro do número de vagas deve ser devidamente motivada e, dessa forma, passível de controle pelo Poder Judiciário. [...] (BRASIL, 2011, passim)

A próxima etapa, após a nomeação, é a posse, e o mesmo seguimento de questionamento exsurge: todo candidato nomeado tem direito à posse? A resposta, no caso, é dada pelo literal teor do enunciado de Súmula $\mathrm{n}^{\circ} 16$ do STF: "funcionário nomeado por concurso tem direito à posse".

Assim, atendidas as exigências específicas na forma da lei, o candidato nomeado terá direito à posse, conforme disposto nos arts. 13 e 14 da Lei no 8.112/90. Cumprida a etapa, o candidato deverá entrar em exercício em até, no máximo, 15 dias. Investido efetivamente no cargo, passará por um estágio probatório, no qual serão apurado itens de natureza prática que não têm como ser percebidos durante a seletiva.

Serão identificados aspectos como assiduidade, produtividade, disciplina, respeito à hierarquia e subordinação, capacidade de iniciativa, ou seja, sua eficiência em relação às suas atribuições no cargo. Durante o período de estágio, podem ser percebidos três cenários: extinção do cargo, reprovação ou aprovação no estágio.

Na primeira hipótese, em caso de extinção do cargo (que pode ocorrer por diversos motivos, como a ausência de necessidade da função ou cortes orçamentários), tem-se o desfecho traçado pelo teor do enunciado de Súmula $n^{\circ} 22$ do Supremo Tribunal Federal que “o estágio probatório não protege o funcionário contra a extinção do cargo".

No caso de reprovação no estágio probatório, serão duas as hipóteses: exoneração do cargo, ou demissão. As duas figuras importam na extinção do cargo. A diferença é que a exoneração não está relacionada com nenhum ilícito; já a demissão pressupõe a prática de ilícito. Porém, em todo caso, deverá ser instaurada inquérito administrativo, sendo assegurada a ampla defesa, conforme Súmula 21 do Supremo: "funcionário em estágio probatório não pode ser exonerado nem demitido sem inquérito ou sem as formalidades legais de apuração de sua capacidade". 
Já em decorrência da aprovação no estágio probatório, tem-se, via de regra, a estabilidade. Contudo, existem algumas exceções previstas no texto constitucional pelas quais, após o período de estágio probatório, é adquirida vitaliciedade - esse caso tem que ser expresso - como são as carreiras da Magistratura, na forma do artigo 95, inciso I, e do Ministério Público, na forma do artigo 128, §5º inciso I, “a”, da Constituição da República.

Enquanto a vitaliciedade assegura a permanência no cargo, a estabilidade tem algumas nuances que devem ser analisadas. Inicialmente, ressalta-se que a estabilidade difere-se da vitaliciedade, pois aquela garante a permanência no serviço. Assim, em sintonia com o artigo 41 da Constituição, que em seu caput exclui os cargos em comissão, os parágrafos do dispositivo garantem ao servidor a disponibilidade remunerada em caso de extinção ou declaração de desnecessidade do cargo, hipótese na qual o indivíduo terá vencimentos proporcionais ao tempo de serviço até posterior reaproveitamento.

Destaca-se, ainda nesse artigo, em seu $\S^{\circ}$, a previsão de avaliação especial de desempenho, porém, como ainda não existe lei específica para regulamentar o tema, considera-se essa como uma norma de eficácia limitada.

Nessa seara, cumpre ressaltar, ainda, a existência de uma extensão da estabilidade prevista no artigo 41 do texto constitucional, em acordo com o enunciado de Súmula $\mathrm{n}^{\circ} 390$ do Tribunal Superior do Trabalho, que assim dispõe:

[...] I - O servidor público celetista da administração direta, autárquica ou fundacional é beneficiário da estabilidade prevista no art. 41 da CF/1988. (ex-OJs $\mathrm{n}^{\circ} \mathrm{S} 265$ da SBDI-1 - inserida em 27.09.2002 - e 22 da SBDI-2 - inserida em 20.09.2000)

II - Ao empregado de empresa pública ou de sociedade de economia mista, ainda que admitido mediante aprovação em concurso público, não é garantida a estabilidade prevista no art. 41 da CF/1988. (ex-OJ no 229 da SBDI-1 - inserida em 20.06.2001). (BRASIL, 2005)

Em atenção ao item II da súmula, ressalta-se a existência da estabilidade atípica, prevista na Lei Federal $n^{\circ}$ 9.986/00, em seu artigo $9^{\circ}$, que atribui a estabilidade aos dirigentes de Agências Reguladoras durante o mandato, observando-se que estes não prestaram provas de concurso, por isso a atipicidade.

Em relação à perda do cargo por servidor estável, tem-se a matéria disciplinada no mesmo artigo $41, \S 1^{\circ}$, que assegura a perda do cargo apenas por sentença judicial com trânsito em julgado, processo administrativo com ampla defesa por insuficiência de desempenho ou pela avaliação periódica que depende de Lei complementar ainda não editada.

A Constituição da República, em seu artigo 169, traz uma hipótese de exoneração do cargo, até mesmo para servidores estáveis, por razão de corte de gasto; mesmo que, no "final 
da fila", é assegura à Administração Pública a possibilidade. Dessa forma, existe limite de gastos com folha de pessoal para as quatro esferas de governo, incluindo-se ativos e inativos, além dos limites fixados em Lei Complementar (artigo 19, LC 101/00, que traz os valores máximos para cada esfera de governo).

Assim, a solução prevista no dispositivo constitucional (art 169, §4, $\mathrm{CR} / 88$ ) é a extinção de $20 \%$ dos cargos em comissão, exoneração de servidores não estáveis, e, caso as medidas sejam insuficientes, "o servidor estável poderá perder o cargo, desde que ato normativo motivado de cada um dos Poderes especifique a atividade funcional, o órgão ou unidade administrativa objeto da redução de pessoal", em acordo com a literalidade da norma.

Encerrado o assunto, ressaltam-se alguns pontos sobre a remuneração desses servidores, e, nesse sentido, encontram-se dois tipos de sistemas: subsídios e vencimentos.

Adentrando nos conceitos, tem-se por subsídio a remuneração em parcela única, pela qual se proíbe a percepção de vantagens. A Constituição vigente apresenta expressamente quem pode receber subsídio: detentores de mandatos eletivos, membros de poder, secretários estaduais e municipais, magistrados (artigo 95, CR/88), membros do Ministério Público (artigo 128, CR/88) e integrantes das carreiras policiais previstas no artigo 144 do texto constitucional.

O vencimento é o salário base do servidor, acrescido das vantagens que o mesmo vai adquirindo ao longo do tempo. Em acordo com a previsão constitucional contida no artigo 37, inciso XI, o teto será o do subsídio mensal dos Ministros do Supremo Tribunal Federal. Ressalta-se que o salário base mais as vantagens não podem ultrapassar o teto ${ }^{167}$, em acordo com a previsão da Emenda Constitucional n 41/2003.

Dentro do tema, é importante ressaltar a existência de um piso salarial, e que a redução da remuneração, de acordo com o artigo 37, inciso XV, é percebida de forma inconstitucional. Além disso, em sintonia com o artigo 48 da Lei $n^{\circ} 8.112 / 90$, a verba tem natureza jurídica alimentar. Sendo assim, não pode ser objeto de arresto, penhora ou sequestro, tendo como exceção apenas a hipótese de dívida que também ostente caráter alimentar.

\footnotetext{
${ }^{167} \mathrm{Na}$ temática concernente à remuneração dos servidores, destaca-se o caso de acumulação de cargos, decidido pelo STF em abril de 2017, em sede de repercussão geral, no julgamento que definiu que, na hipótese de acumulação de cargos, a remuneração dos cargos isolados não poderá superar o teto: "TETO CONSTITUCIONAL - ACUMULAÇÃO DE CARGOS - ALCANCE. Nas situações jurídicas em que a Constituição da República autoriza a acumulação de cargos, o teto remuneratório é considerado em relação à remuneração de cada um deles, e não ao somatório do que recebido. (RE 612975, Relator(a): Min. MARCO AURÉLIO, Tribunal Pleno, julgado em 27/04/2017, ACÓRDÃO ELETRÔNICO REPERCUSSÃO GERAL MÉRITO DJe-203 DIVULG 06-09-2017 PUBLIC 08-09-2017)”.
} 


\section{A INTERFERÊNCIA DO PODER JUDICIÁRIO NA REVISÃO DE QUESTÕES DE PROVAS DE CONCURSOS PÚBLICOS}

A análise a ser aqui discorrida tem como base principal a jurisprudência, uma vez que o tema é de grande incidência e relevância no cenário atual brasileiro, tendo em vista o incremento do número de candidatos inscritos em concursos públicos como resultado da crise econômica e da busca humana pela estabilidade e segurança financeira.

Voltando aos princípios do regime jurídico administrativo, cumpre ressaltar que os editais são atos da Administração Pública, e, por isso, estão submetidos a todos os princípios que regem o atuar administrativo. Logo, conforme tratado anteriormente, as determinações dos editais devem ser sempre motivadas e respaldadas na legislação da carreira, dotadas de razoabilidade, ou então serão ilícitas, podendo ser remediadas judicialmente.

Cumpre ressaltar, ainda, a relevância da discricionariedade, que garante às bancas de concursos públicos a autonomia na edição de seus atos. É a própria liberdade de ação administrativa dentro dos limites legislativos. Não obstante, a lei deixa certa margem de decisão perante casos concretos, de modo que a autoridade administrativa poderá levar o administrador público a optar por alguma dentre as variadas opções possíveis, porém válidas, que lhe são disponibilizadas pelo império da lei.

Dessa forma, a discricionariedade, que traz esse leque de liberdade para as decisões acerca das questões referentes ao concurso dentro dos limites da lei, cumulada ao princípio da autotutela, que garante à correção, anulação e modificação dos atos administrativos em acordo com o interesse público, afasta do Judiciário a prerrogativa de interferir nas decisões referentes aos concursos, eis que somente é cabível o acionamento da via judicial frente aos atos administrativos que importarem em ilegalidade.

Nessa seara, destaca-se a lição de Gustavo Binenbojm, (2014, p. 219-222):

A emergência da noção de juridicidade administrativa, com a vinculação direta da Administração à Constituição, não mais permite falar, tecnicamente, numa autêntica dicotomia entre atos vinculados e atos discricionários, mas, isto sim, em diferentes graus de vinculação dos atos administrativos à juridicidade. A discricionariedade não é, destarte, nem uma liberdade decisória externa ao direito, nem um campo imune ao controle jurisdicional. Ao menor ou menor grau de vinculação do administrador à juridicidade corresponderá, via de regra, maior ou menor grau de controlabilidade judicial de seus atos. [...]. Deste modo, ao invés de uma dicotomia em moldes tradicionais (ato vinculado v. ato discricionário), já superada, passa-se a uma classificação em graus de vinculação à juridicidade, em uma escala decrescente de densidade normativa vinculativa: a) atos vinculados por regras (constitucionais, legais ou regulamentares); b) atos vinculados por conceitos jurídicos indeterminados (constitucionais, legais ou regulamentares); c) atos vinculados diretamente por princípios (constitucionais, legais ou regulamentares)". 
Evidentemente, nota-se que o principal percalço inerente às discussões de questões de concursos públicos passa pela identificação de ilegalidades dos parâmetros que devem ser observados para analisar a necessidade de interferência do Judiciário quanto à alteração/anulação dessas questões, suplantando a autonomia da banca. Para isso, deve ser feita uma análise jurisprudencial acerca do tema, ressaltando-se os pontos observados, as divergências entre as cortes, e o atual cenário da problemática.

\section{PERSPECTIVA JURISPRUDENCIAL SOBRE O TEMA}

Em relação a alguns pontos de um processo seletivo de concurso público, é fácil identificar eventual ilegalidade e a necessidade de interferência judicial, como é o caso do direito subjetivo à nomeação, à exclusão de candidatos com carência de motivação, ou até ao não seguimento da ordem de classificação. Já a revisão de questões elaboradas pela banca sob o argumento de "carecer de alternativa correta" ou de "correção feita de forma incorreta com os padrões jurídicos" ou até mesmo por "ter mais de uma alternativa correta" cruza uma linha tênue entre o inconformismo e a ilegalidade, e há muitos anos complica as decisões do Judiciário acerca do tema, mesmo que existam precedentes e entendimentos consolidados, como será exposto.

Fato é que a jurisprudência toma, há muitos anos, uma postura defensiva em relação à revisão de questões de concursos públicos. Ainda em 1990, o então Ministro do STF Aldir Passarinho, no julgamento do MS 21.176, ressaltou que não compete ao Judiciário substituir a banca examinadora para reexaminar o conteúdo de questões e os critérios de correção utilizados, ressalvadas as hipóteses de ilegalidade e inconstitucionalidade.

No mesmo sentido, a Ministra Carmem Lúcia, no julgamento do MS 27.260, em 2010, ressaltou que a alteração de resposta do gabarito, entre o preliminar e o final, não acarreta nulidade do concurso caso se tenha previsão para tanto no edital.

$\mathrm{O}$ argumento daqueles que defendem teses de interferência do Poder Judiciário de forma mais incisiva no campo da revisão de questões de concurso é o de que, como as provas devem estar norteadas pela razoabilidade, a elaboração de questões também deve ser razoável, conforme as indicações dos editais, não obstante a inafastabilidade da tutela jurisdicional exista para garantir remédio judicial às problemáticas das provas. 
Um dos grandes pontos observados pela Suprema Corte nos últimos anos diz respeito à sobreposição do controle judicial ao entendimento firmado pela banca em face dos princípios que garantem à Administração a independência na edição de seus atos, colocando o entendimento de alguns magistrados como superior àquele firmado pelos membros da banca.

A análise pauta-se em suposta ofensa à separação dos poderes e à própria reserva da Administração, e atribui pontos à alguns candidatos em detrimento dos demais, causando uma negativa repercussão em contrário ao princípio da isonomia, que é um dos principais pilares da realização de provas sem identificação subjetiva de candidatos, para que os critérios de correção sejam os mais objetivos, sem diferenciação individual.

De fato, o Judiciário tenta se afastar da situação pela problemática que envolve, e toma posicionamento minimalista, tendo em vista que pode interferir diretamente nos indivíduos que serão investidos no cargo público. ${ }^{168}$

Noutro norte, adentra-se em outra grande questão: como far-se-á a revisão de questões que não versam sobre temas jurídicos? A resposta inicial seria a realização de perícia. Mas, os peritos seriam mais confiáveis do que a própria banca? O entendimento de um médico nomeado pelo Poder Judiciário seria suficiente para calar os membros capacitados eleitos para a banca? Assim, vê-se a problemática de se adentrar no mérito da correção de questões, pois a interpretação e análise das doutrinas previstas no edital é o próprio trabalho da banca, o que se traduz em enorme nebulosidade.

Contudo, como os atos administrativos estão vinculados aos princípios e determinações constitucionais, fato é o Judiciário deve exercer papel no controle desses atos praticados pelas bancas de concurso quando se tratarem de questões evidentemente teratológicas e em flagrante incompatibilidade com o edital, ou seja, naquilo que estiver posto em detrimento do edital, estar-se-á a ferir a própria moralidade, a legalidade e a razoabilidade do processo seletivo, gerando ilegalidade passível de remédio judicial. ${ }^{169}$

\footnotetext{
$168 \mathrm{O}$ primeiro precedente relativo a esse ponto e que deve ser analisado é do Supremo Tribunal Federal: "Recurso extraordinário com repercussão geral. 2. Concurso público. Correção de prova. Não compete ao Poder Judiciário, no controle de legalidade, substituir banca examinadora para avaliar respostas dadas pelos candidatos e notas a elas atribuídas. Precedentes. 3. Excepcionalmente, é permitido ao Judiciário juízo de compatibilidade do conteúdo das questões do concurso com o previsto no edital do certame. Precedentes. 4. Recurso extraordinário provido. (RE 632853, Relator(a): Min. GILMAR MENDES, Tribunal Pleno, julgado em 23/04/2015, ACÓRDÃO ELETRÔNICO REPERCUSSÃO GERAL - MÉRITO DJe-125 DIVULG 26-06-2015 PUBLIC 29-06-2015)".

169 O STF firmou entendimento relativo a esta questão em julgado veiculado em seu Informativo 677. Em conclusão de julgamento, a $1^{a}$ Turma, por maioria, concedeu, em parte, mandado de segurança a fim de anular questões objetivas de concurso público para provimento de cargo de Procurador da República, em virtude de equívoco na elaboração destas - v. Informativos 658 e 660. Afirmou-se que, observada erronia no gabarito da prova objetiva, deveria ser reapreciada a situação jurídica do impetrante pela comissão do concurso. (MS 30.859/DF, rel. Min. Luiz Fux, 28.8.2012).
} 
Também é imperioso ao magistrado, quando se deparar com uma ação que tenha por objeto a revisão de questões de concursos, constatar se a anulação ou alteração daquela questão irá garantir a continuidade do candidato no processo, pois caso contrário, considera-se ausente o interesse de agir, condição da ação devidamente prevista no artigo 330 do Código de Processo Civil. Este tema foi analisado pelo STF no MS 30.859.

O Superior Tribunal de Justiça tem precedentes no mesmo sentido, mantendo-se minimalista e tratando das exceções apenas em relação a questões objetivas, uma vez que as questões subjetivas, exatamente pela sua natureza, dificultam uma interpretação que seja flagrante de incoerência com o edital, eis que depende de diversos fatores em sua correção, sendo a atribuição de décimos e pontos muito além da possibilidade de interferência do Judiciário. ${ }^{170} \mathrm{E}$, para além disso, é importante frisar que o cenário atual da jurisprudência do Superior Tribunal de Justiça é de unanimidade, uma vez que ambas as turmas que julgam temas de direito público (primeira e segunda) mantêm o mesmo entendimento.

Como já exposto, a possibilidade de interferência do Judiciário na alteração de questões objetivas não recai em inconformismos ou divergências doutrinárias, mas apenas em requisitos objetivos estipulados no próprio edital. Dessa forma, em relação às questões subjetivas, tem-se consolidada a impossibilidade de remédio judicial. ${ }^{171}$

É certo que, quanto menos objetiva for a prova, mais detalhado deverá ser o gabarito, a fim de que sejam evitadas interferências subjetivas do examinador na correção das provas. Obviamente, contudo, no caso de questões escritas, deve ser elaborado um roteiro com todas as informações que se espera do candidato em sua resposta final, com as notas correspondentes, notadamente quando outras habilidades tiverem que ser avaliadas, como

\footnotetext{
170 Tem-se, a esse respeito, dois importantes paradigmas jurisprudenciais da lavra do STJ: “[...]. Na hipótese de flagrante ilegalidade de questão objetiva de prova de concurso público ou ausência de observância às regras previstas no edital, tem-se admitido sua anulação pelo Judiciário por ofensa ao princípio da legalidade. Precedentes do STJ. [...] (AgRg no AREsp 165.843/RJ, Min. Herman Benjamin, Segunda Turma, julgado em 07/08/2012)"; e, ainda: “[...]. 2. A competência do Poder Judiciário, em se tratando de concurso público, limitase ao exame da legalidade das normas instituídas no edital e dos atos praticados na realização do certame, sendo vedado o exame dos critérios de formulação de questões, de correção de provas, atribuição de notas aos candidatos, matérias cuja responsabilidade é da banca examinadora. 3. Excepcionalmente, em havendo flagrante ilegalidade de questão objetiva de prova de concurso público - o que não inclui, por óbvio, a prova de dissertação impugnada pelos recorrentes - ou a ausência de observância às regras previstas no edital, tem-se admitido sua anulação pelo Judiciário por ofensa ao princípio da legalidade. [...] (AgRg no REsp 1.260.777/SC, Rel. Min. Castro Meira, Segunda Turma, julgado em 06/03/2012)".

${ }^{171}$ Com efeito, tem-se o precedente: “[...]. Com efeito, o fato de o edital não fazer menção expressa que exigiria do candidato o conhecimentos acerca do entendimento dos Tribunais Superiores não é, por si só, óbice que impeça a banca examinadora de promover a cobrança de conhecimentos de forma multidisciplinar. Isso porque, em se tratando de prova discursiva, não raro se exige do candidato a capacidade de examinar a matéria sob o ponto de vista de um sistema de normas, diplomas e posicionamentos jurisprudenciais que se relacionam entre si (fls. 378). 4. Agravo Interno do particular a que se nega provimento. (AgInt no RMS 50.769/BA, Rel. Ministro Napoleão Nunes Maia Filho, Primeira Turma, julgado em 01/03/2018, DJe 12/03/2018)"
} 
clareza na exposição do raciocínio, uso da Língua Portuguesa etc., e isto porque a principal função do gabarito é orientar o examinador na correção das provas, vinculando sua atuação e garantindo a objetividade dos resultados.

\section{CONSIDERAÇÕES FINAIS}

Apresentadas as principais teses firmadas pelas Cortes Superiores, com a irradiação de alguns posicionamentos doutrinários e a compreensão dos princípios que regem o regime jurídico brasileiro, tem-se que o leque de cognoscibilidade da interferência do Judiciário nas questões de concurso público para provimento de cargos efetivos traz diversos apontamentos e divergências, tendo em vista o "choque" entre princípios constitucionais e a linha tênue que separa o que seria ilegal e o que interfere na separação dos poderes.

Contudo, a partir da análise jurisprudencial apresentada, além das discussões de controle administrativo e judicial dos atos da Administração Pública, conclui-se que a posição adotada pela jurisprudência majoritária, em consonância com as Cortes Superiores, é, de fato, o melhor caminho para que se possa manter o controle jurisdicional e a autonomia administrativa em sintonia.

Percebem-se alguns pontos de dificuldade nesta análise, devendo o magistrado julgador, ao se deparar com a temática, analisar as peculiaridades de cada caso, objetivando sua análise no edital e na legislação para, então, analisar o posicionamento técnico adotado pela banca.

Ante ao exposto, tem-se que o juízo não pode controlar a pertinência do exame aplicado ao conteúdo discriminado no edital, de forma a apreciar os critérios de avaliação e a conexão técnica com o gabarito oficial. Complicada nessa esfera a elaboração de perícias para temas não jurídicos, uma vez que, ante a ausência de conhecimento absoluto, considerar a abordagem pericial como superior à da banca torna-se complexo e controvertido.

A grande questão que deve ser compreendida perpassa pela avaliação da existência de pessoas designadas e selecionadas, nas bancas, para fazer a análise do conteúdo e decidir a melhor forma de avaliar os candidatos. Assim, a realização de perícias quanto ao conteúdo de questões ligadas às diversas áreas do conhecimento (exceto ao Direito) e a própria apreciação do Judiciário quanto às respostas de questões de Direito, suplantaria o presumível conhecimento dos membros eleitos para a composição da banca do concurso, admitindo-se entendimentos "superiores" a outros. 
No caso de erro grotesco e de conteúdos óbvios, tem-se que a própria banca goza dos benefícios do princípio da autotutela para alterar seus atos em caso de constatação desses erros, e, em regra, as bancas abrem prazos recursais administrativos para a contestação de questões, ou seja, o Judiciário deve visto como a última opção dentro deste cenário - sem, com isso, defender-se qualquer esvaziamento do princípio da inafastabilidade do controle jurisdicional - a fim de se garantir segurança jurídica ao certame e a própria isonomia entre os candidatos.

Ademais, no caso de uma revisão de gabarito não motivada, exclusão de candidato sem razão, tem-se ato notoriamente inconstitucional, e, então, dentro dessas hipóteses, mostra-se cabível e até mesmo necessário o remédio judicial.

Cumpre observar que o posicionamento minimalista do Judiciário, apresentando uma jurisprudência defensiva, não fere, por si só, a inafastabilidade da tutela jurisdicional prevista como direito fundamental no artigo $5^{\circ}$, incisos XXXIV, "a", e XXXV, da Constituição da República, que assegura a todos, independentemente do pagamento de taxas, o direito de petição aos Poderes Públicos em defesa de direitos ou contra a ilegalidade ou abuso de poder.

Ademais, considerando que o ato administrativo goza da presunção de legitimidade, cumpre ressaltar que o ônus probatório quanto à ilegalidade do ato recai sobre aaquele que a invoca. Sendo assim, na espécie, caberia ao interessado que prestou a prova demonstrar a ilegalidade constante no ato, preservando-se o contraditório e a ampla defesa, razão pela qual a ação recomendada para esse tipo de situação é a ação ordinária, em detrimento da via estreita do mandado de segurança.

\section{REFERÊNCIAS}

ARAúJO, Edmir Netto de. Curso de Direito Administrativo. 5. ed. São Paulo: Saraiva, 2010.

BINENBOJM, Gustavo. Uma teoria do Direito Administrativo: direitos fundamentais, democracia e constitucionalização. 3. ed. Rio de Janeiro: Renovar, 2003.

BRASIL. Constituição da República Federativa do Brasil. Brasília: Senado Federal, 1988. Disponível em: < http://www.planalto.gov.br/ccivil_03/constituicao/constituicao.htm >. Acesso em: 10 jul. 2018. 
BRASIL. Emenda Constitucional $\mathrm{n}^{\circ}$ 41, de 19 de dezembro de 2003. Modifica os arts. 37, 40, 42, 48, 96, 149 e 201 da Constituição Federal, revoga o inciso IX do $\$ 3$ do art. 142 da Constituição Federal e dispositivos da Emenda Constitucional $\mathbf{n}^{\circ}$ 20, de 15 de dezembro de 1998, e dá outras providências. In: Diário Oficial da República Federativa do Brasil, Brasília, DF, 31 dez. 2003. Disponível em: < http://www.planalto.gov.br/ccivil_03/Constituicao/Emendas/Emc/emc41.htm >. Acesso em: 18 jul. 2018.

BRASIL. Lei $\mathrm{n}^{\circ}$ 8.112, de 11 de dezembro de 1990. Dispõe sobre o regime jurídico dos servidores públicos civis da União, das autarquias e das fundações públicas federais. In: Diário Oficial da República Federativa do Brasil, Brasília, DF, 19 abr. 1991. Disponível em: < http://www.planalto.gov.br/ccivil_03/leis/L8112cons.htm >. Acesso em: 13 jul. 2018.

BRASIL. Lei $\mathrm{n}^{\circ}$ 9.986, de 18 de julho de 2000. Dispõe sobre a gestão de recursos humanos das Agências Reguladoras e dá outras providências.. In: Diário Oficial da República Federativa do Brasil, Brasília, DF, 19 jul. 2000. Disponível em: < http://www.planalto.gov.br/Ccivil_03/leis/L9986.htm >. Acesso em: 13 jul. 2018.

BRASIL. Lei Complementar $n^{\circ} 101$, de 04 de maio de 2000. Estabelece normas de finanças públicas voltadas para a responsabilidade na gestão fiscal e dá outras providências.. In: Diário Oficial da República Federativa do Brasil, Brasília, DF, 05 mai. 2000. Disponível em: < http://www.planalto.gov.br/ccivil_03/Leis/LCP/Lcp101.htm >. Acesso em: 13 jul. 2018.

BRASIL. Superior Tribunal de Justiça. Acórdão de decisão proferida em sede de agravo regimental que assentou o entendimento de que, na hipótese de flagrante ilegalidade de questão objetiva de prova de concurso público ou inobservância das regras previstas no edital, admite-se sua anulação pelo Judiciário por ilegalidade. AgRg no AREsp $n^{\circ}$ 165.843/RJ. Relator: Ministro Herman Bejamin. 07 de agosto de 2012. Disponível em: < https://ww2.stj.jus.br/processo/revista/documento/mediado/?componente=ATC\&sequencial= $22889963 \&$ num_registro $=201200745271 \&$ data $=20120822 \&$ tipo $=51 \&$ formato $=$ PDF $\quad>$. Acesso em: 16 jul. 2018.

BRASIL. Superior Tribunal de Justiça. Acórdão de decisão proferida em sede de agravo regimental que assentou o entendimento de que a competência do Poder Judiciário, em se tratando de concurso público, limita-se ao exame da legalidade das normas instituídas no edital e dos atos praticados na realização do certame. AgRg no REsp 1.260.777/SC. Relator: Ministro Castro Meira. 06 de março de 2012. Disponível em: < https://ww2.stj.jus.br/processo/revista/documento/mediado/?componente=ATC\&sequencial= $20374257 \&$ num_registro $=201101366245 \&$ data $=20120316 \&$ tipo $=91 \&$ formato $=P D F \quad>$. Acesso em: 16 jul. 2018.

BRASIL. Superior Tribunal de Justiça. Acórdão de decisão proferida em sede de agravo regimental que assentou o entendimento de que o fato de o edital não fazer menção expressa que exigiria do candidato o conhecimentos acerca do entendimento dos 
Tribunais Superiores não é, por si só, óbice que impeça a banca examinadora de promover a cobrança de conhecimentos de forma multidisciplinar. RMS 50.769/BA. Relator: Napoleão Nunes Maia Filho. 01 de março de 2018. Disponível em: < https://ww2.stj.jus.br/processo/revista/documento/mediado/?componente=MON\&sequencial= 76220859\&num_registro $=201601095630 \&$ data $=20170912 \&$ tipo $=0 \&$ formato $=P D F \quad>$. Acesso em: 16 jul. 2018.

BRASIL. Superior Tribunal de Justiça. Súmula $\mathbf{n}^{\mathbf{0}}$ 377. Disponível em: < http://www.stj.jus.br/SCON/sumulas/doc.jsp?livre=@num=\%27377\%27 >. Acesso em: 13 jul. 2018.

BRASIL. Superior Tribunal de Justiça. Súmula $\mathbf{n}^{\mathbf{0}} \mathbf{5 5 2}$. Disponível em: < http://www.stj.jus.br/SCON/sumulas/doc.jsp?livre=@num=\%27552\%27 >. Acesso em: 13 jul. 2018.

BRASIL. Supremo Tribunal Federal. Acórdão de decisão proferida em sede de mandado de segurança, versando sobre questões de concurso público. Mandado de Segurança $\mathrm{n}^{\circ}$ 21.176. Relator: Ministro Aldir Passarinho. 20 de março de 1992. Disponível em: < http://portal.stf.jus.br/processos/detalhe.asp?incidente=1503200 >. Acesso em: 16 jul. 2018.

BRASIL. Supremo Tribunal Federal. Acórdão de decisão proferida em sede de mandado de segurança, versando sobre questões de concurso público. Mandado de Segurança $\mathrm{n}^{\circ}$ 27.260/DF. Relator: Ministro Ayres Britto. 26 de março de 2010. Disponível em: < http://portal.stf.jus.br/processos/detalhe.asp?incidente=2611018 >. Acesso em: 16 jul. 2018.

BRASIL. Supremo Tribunal Federal. Acórdão de decisão proferida em sede de mandado de segurança, versando sobre questões de concurso público. Mandado de Segurança ${ }^{\circ}$ 30.859/DF. Relator: Ministro Luiz Fux. 28 de agosto de 2012. Disponível em: < http://portal.stf.jus.br/processos/detalhe.asp?incidente=4134056 >. Acesso em: 16 jul. 2018.

BRASIL. Supremo Tribunal Federal. Acórdão de decisão que julgou, em sede de repercussão geral, tema relativo ao direito individual líquido e certo à nomeação que têm os candidatos que forem aprovados dentro do número de vagas previsto em edital de concurso público (inteiro teor). Recurso Extraordinário n ${ }^{\circ}$ 598.099/MS. Relator: Ministro Gilmar Mendes. 10 de agosto de 2011. Disponível em: < http://redir.stf.jus.br/paginadorpub/paginador.jsp?docTP=AC\&docID=609362 >. Acesso em: 15 jul. 2018.

BRASIL. Supremo Tribunal Federal. Acórdão de decisão que julgou, em sede de repercussão geral, tema no sentido de que os critérios adotados por banca examinadora de um concurso público não podem ser revistos pelo Poder Judiciário. Recurso Extraordinário $\mathrm{n}^{\mathrm{o}}$ 632.853/CE. Relator: Ministro Gilmar Mendes. 23 de abril de 2015. 
Disponível em: < http://portal.stf.jus.br/processos/detalhe.asp?incidente=3992645 >. Acesso em: 16 jul. 2018.

BRASIL. Supremo Tribunal Federal. Acórdão de decisão que julgou, em sede de repercussão geral, tema relativo ao direito à percepção cumulativa de parcelas de aposentadoria frente ao teto remuneratório (inteiro teor). Recurso Extraordinário $\mathrm{n}^{\circ}$ 612.975/MS. Relator: Ministro Marco Aurélio. 27 de abril de 2017. Disponível em: < http://redir.stf.jus.br/paginadorpub/paginador.jsp?docTP=AC\&docID=622231 >. Acesso em: 17 jul. 2018.

BRASIL. Supremo Tribunal Federal. Súmula $\mathbf{n}^{\mathbf{0}}$ 15. Disponível em: < http://www.stf.jus.br/portal/jurisprudencia/menuSumarioSumulas.asp?sumula=1456 >. Acesso em: 13 jul. 2018.

BRASIL. Supremo Tribunal Federal. Súmula $\mathbf{n}^{\mathbf{0}}$ 16. Disponível em: < http://www.stf.jus.br/portal/jurisprudencia/menuSumarioSumulas.asp?sumula=2083 >. Acesso em: 13 jul. 2018.

BRASIL. Supremo Tribunal Federal. Súmula $\mathbf{n}^{\mathbf{0}}$ 21. Disponível em: < http://www.stf.jus.br/portal/jurisprudencia/menuSumarioSumulas.asp?sumula=2106 >. Acesso em: 13 jul. 2018.

BRASIL. Supremo Tribunal Federal. Súmula $\mathbf{n}^{\mathbf{0}}$ 22. Disponível em: < http://www.stf.jus.br/portal/jurisprudencia/menuSumarioSumulas.asp?sumula=2110 >. Acesso em: 13 jul. 2018.

BRASIL. Supremo Tribunal Federal. Súmula Vinculante $\mathbf{n}^{\mathbf{0}}$ 13. Disponível em: < http://www.stf.jus.br/portal/jurisprudencia/menuSumario.asp?sumula=1227 >. Acesso em: 13 jul. 2018.

BRASIL. Tribunal Superior do Trabalho. Súmula $\mathbf{n}^{\mathbf{0}}$ 390. Disponível em: < http://www3.tst.jus.br/jurisprudencia/Sumulas_com_indice/Sumulas_Ind_351_400.html\#SU M-390 >. Acesso em: 13 jul. 2018.

CARVAlHO FILHO, José dos Santos. Manual de Direito Administrativo. 30. ed. São Paulo: Atlas, 2016.

CAVALCANTI, Temístocles Brandão. O funcionário público e o seu estatuto, Rio de Janeiro: Freitas Bastos, 1940. 
CRETELla JÚNIOR, José. Direito Administrativo Brasileiro. 2. ed. Rio de Janeiro: Forense, 2000.

DI PIETRO, Maria Sylvia Zanella. Direito Administrativo. 20. ed. São Paulo: Atlas, 2007.

FALDINI, Cristiana Corrêa Conde. A constitucionalização do Direito Administrativo. In: DI PIETRO, Maria Sylvia Zanella; RIBEIRO, Carlos Vinícius Alves (Coord.). Supremacia do interesse público e outros temas relevantes do Direito Administrativo. São Paulo: Atlas, 2010.

FERRAJOLI, Luigi. Garantismo: una discusión sobre derecho y democracia. Madrid: Trotta, 2006.

FREITAS, Juarez. O controle dos atos administrativos e os princípios fundamentais. 3. ed. São Paulo: Malheiros, 2004.

GUASTINI, Ricardo. La “constitucionalización” del ordenamiento jurídico. In: CARBONELL, Miguel (Org.). Neoconstitucionalismo(s). Madrid: Trotta, 2003.

HARGER, Marcelo. A discricionariedade e os conceitos jurídicos indeterminados. Revista dos Tribunais, São Paulo, v. 765, p. 11-36, out. 1998.

MEIRELLES, Hely Lopes. Direito Administrativo Brasileiro. 42. ed. São Paulo: Saraiva, 2016.

MELlO, Celso Antônio Bandeira de. Curso de Direito Administrativo. 20. ed. São Paulo: Maleiros, 2006.

MIRAGEM, Bruno. A nova Administração Pública e o Direito Administrativo. 2. ed. São Paulo: Revista dos Tribunais, 2013.

MODESTO, Paulo. Estágio Probatório: questões controversas. Revista Diálogo Jurídico, Salvador: Centro de Atualização Jurídica, n. 12, mar. 2002.

MOREIRA NETO, Diogo de Figueiredo. Curso de Direito Administrativo. 14. ed. Rio de Janeiro: Forense, 2006.

MOTTA, Fabrício. Concurso Público e Constituição. Belo Horizonte: Fórum, 2005. 
ROCHA, Francisco Lobello de Oliveira. Regime jurídico dos concursos públicos. São Paulo: Dialética, 2006.

RODRÍGUEZ-ARANA MUÑOZ, Jaime. El marco constitucional del Derecho Administrativo: el Derecho Administrativo Constitucional. Anuario da Faculdade de Dereito da Universidade da Coruña, Coruña, n. 15, p. 87-102, 2011.

SPITZCOVSKY, Celso. Direito Administrativo. 14. ed. São Paulo: Método, 2013.

STRECK, Lenio Luiz. Ontem, os Códigos; hoje, as Constituições: o papel da hermenêutica na superação do positivismo pelo neoconstitucionalismo. In: ROCHA, Fernando Luiz Ximenes; MORAES, Filomeno (Org.). Direito Constitucional contemporâneo: estudos em homenagem ao professor Paulo Bonavides. Belo Horizonte: Del Rey, 2005.

VIANA, Ruth Araújo. O princípio da juridicidade e os princípios constitucionais como instrumentos para o controle eficaz dos atos administrativos discricionários. In: SILVA, Maria Teresinha Pereira; ZANOTELLI, Maurício (Coord.). Direito e Administração Pública: por uma hermenêutica compatível com os desafios contemporâneos. Curitiba: Juruá, 2011.

\title{
THE RANGE OF THE JUDICIARY'S COGNOSCIBILITY ON QUESTIONS OF EFFECTIVE POSITIONS PROVISIONS THROUGH PUBLIC CONCOURSES
}

\begin{abstract}
This paper aims to analyze the Judiciary's interference in public concourses questions by delimitating the more common arguments and theories that plaintiffs invoke to then try to comprehend the jurisprudential positions usually adopted by Brazilian courts. In order to accomplish that, this research will engage the main characteristics of the Brazilian administrative regime by showcasing the norms and principles that guide Public Administration for that matter. Afterwards, the categories of public agents will be approached to delimitate their functions and how they work. Thus, utilizing the inductive method by presenting jurisprudential precedents related to the theme at hand, the paper analyses the hypothesis of a minimalistic posture by the Judiciary branch regarding the review of public concourses questions' contents when submitted to its judgement.
\end{abstract}

Keywords: Public concourses. Questions. Judiciary branch. 